\title{
Biochemical and hormonal changes associated with root growth restriction under cadmium stress during maize (Zea mays $L$.) pre-emergence
}

\author{
Carolina L. Matayoshi ${ }^{1} \cdot$ Liliana B. Pena $^{1,2}$ (1) $\cdot$ Vicent Arbona $^{3} \cdot$ Aurelio Gómez-Cadenas $^{3} \cdot$ Susana M. Gallego ${ }^{1,2}$
}

Received: 27 May 2021 / Accepted: 7 November 2021 / Published online: 18 November 2021

(c) The Author(s), under exclusive licence to Springer Nature B.V. 2021

\begin{abstract}
Cadmium $(\mathrm{Cd})$ pollution of agricultural soils is a growing global concern. Plant growth restriction is the main visible symptom of Cd toxicity, and this metal may be particularly harmful to the preformed, seminal root during the pre-emergence stage. In the present study, we focused on Cd phytotoxicity in seminal root growth, nutrient composition, redox status, and hormone homeostasis during the pre-emergence stage of maize (Zea mays $\mathrm{L}$ ) plants, distinguishing between the root apex and the remaining root tissue. After $72 \mathrm{~h}$ of metal exposure (50 and $100 \mu \mathrm{M} \mathrm{CdCl}_{2}$ ), root length and biomass, as well as Ca, $\mathrm{Fe}, \mathrm{Mg}$, and $\mathrm{Mn}$ contents, were diminished. A redox imbalance was evidenced by changes in peroxidase activities and the ascorbate-dehydroascorbate ratio decreased in both root parts. There were fewer carbonylated proteins in both root fractions after exposure to $50 \mu \mathrm{M} \mathrm{Cd}$, compared to $100 \mu \mathrm{M} \mathrm{Cd}$, which was related to increased 20S proteasome activities. Cd incremented ABA, IAA, and SA contents, but drastically reduced the biologically active gibberellin GA4 and the conjugate jasmonoyl-isoleucine (JA-Ile). We demonstrated that the whole root tissue is involved in the maize response to Cd stress, which entails redox and hormonal rearrangements, probably directed to widen the plant defense lines at the expense of root growth.
\end{abstract}

Keywords Heavy metals · Phytohormones · Protein carbonylation

Communicated by Naser A. Anjum.

\section{Liliana B. Pena}

lpena@ffyb.uba.ar

Susana M. Gallego

sgallego@ffyb.uba.ar

1 Facultad de Farmacia y Bioquímica, Departamento de Química Biológica, Universidad de Buenos Aires, Buenos Aires, Argentina

2 Instituto de Química y Fisicoquímica Biológicas (IQUIFIB), Universidad de Buenos Aires. Consejo Nacional de Investigaciones Científicas y Técnicas, Buenos Aires, Argentina

3 Departament de Ciències Agràries i del Medi Natural, Universitat Jaume I, Ecofisiologia i Biotecnologia. Campus Riu Sec, 12071 Castelló de la Plana, Spain

\section{Introduction}

Cadmium $(\mathrm{Cd})$ is a transition metal ion released into the environment by industrial activities and urbanization. In cultivated soils, $\mathrm{Cd}$ derives mainly from $\mathrm{P}$ fertilizers (Sterckeman et al. 2018). Due to its relatively high mobility and high toxicity for living organisms-even at very low doses-, cadmium is considered a particularly dangerous pollutant (Vardhan et al. 2019). The increasing contamination of soil and food crops represents a serious global problem nowadays (Rehman et al. 2018; Dala-Paula et al. 2018; Cai et al. 2019). Plant growth restriction is one of the main visible symptoms of Cd phytotoxicity (Gallego et al. 2012). Despite being a redox-inactive metal, $\mathrm{Cd}$ toxicity has been partly associated with oxidative stress production (Gallego and Benavides 2019).

It is known that plant growth regulation and plant responses to stress depend on the interplay between hormonal and redox balances (Santner and Estelle 2009; De Tullio et al. 2010; Bartoli et al. 2013). Plant hormones comprise a series of natural compounds required at low concentrations 
to fulfill their function. While each plant hormone has its specific pathway that acts in a non-redundant way, their activities are interconnected by a complex network, and it is the interaction and cooperation between hormones that dynamically regulate plant development and physiology (Vanstraelen and Benková 2012). It has been described that the exogenous application of phytohormones reduces the toxic effects of metals, in part through the improvement of the cell antioxidant potential (Singh et al. 2016).

On the other hand, it is known that plant cell redox homeostasis is controlled by a complex system known as the Foyer-Halliwell-Asada pathway that is responsible for reactive oxygen species (ROS) scavenging (Foyer and Noctor 2011). This antioxidant defense machinery includes several enzymes such as superoxide dismutase (SOD, EC 1.15.1.1), which converts superoxide anion $\left(\mathrm{O}_{2}{ }^{-}\right)$to $\mathrm{H}_{2} \mathrm{O}_{2}$, catalase (CAT, EC 1.11.1.6), ascorbate peroxidase (APX, EC 1.11.1.11), and a variety of general peroxidases that catalyze the breakdown of $\mathrm{H}_{2} \mathrm{O}_{2}$. Non-enzymatic antioxidants include low molecular weight compounds, such as glutathione (GSH) and ascorbic acid (ASC) (Foyer and Noctor 2016). Nevertheless, an excessive ROS production that overwhelms the protective antioxidant mechanism can occur when plants are subjected to adverse environmental conditions (Gill and Tuteja 2010). A consequence of cell redox imbalance is protein oxidative damage, commonly expressed by carbonyl group increases (Møller et al. 2007). Carbonylated proteins can form high-molecular-weight aggregates that compromise several cellular functions (Nyström 2005). Because protein carbonylation is a covalent, non-reversible modification, oxidatively damaged proteins have to be rapidly degraded, mainly by the $20 \mathrm{~S}$ proteasome activity in the cytoplasm and nucleus (Pena et al. 2007; Polge et al. 2009).

Maize (Zea mays L.) is one of the most important crops used for human and animal diet in the world (Godfray et al. 2010), and in some cases, maize-producing lands are at high risk of cadmium contamination (Chumbley and Unwin 1982; Dharma-Wardana 2018). It has been reported that Cd reduces growth, induces chlorosis, alters chloroplast ultrastructure, produces oxidative damage, modifies cell wall composition, and affects polyamine metabolism in maize plants (Anjum et al. 2015; Vatehová et al. 2016; Seifikalhor et al. 2020). Furthermore, previous data indicate that maize plants tend to retain and accumulate cadmium at the root level (Anjum et al. 2015; Vatehová et al. 2016), where ROS production is induced soon after metal exposure (Liu et al. 2019).

The emergence of maize coleoptile to the soil surface delimits the onset of plant phototrophic lifestyle and takes place 5 to 7 days after planting under favorable, natural conditions (Abendroth et al. 2011). The embryonically preformed root type dominates during this stage of development (Hochholdinger 2009). In addition to being vital for the vigor of young maize plants during the first weeks after germination, the embryonic root system is the first plant organ expected to interact with the underground environment and eventually suffer the toxic effects caused by $\mathrm{Cd}$ present in soils (Tai et al. 2016). Several reports indicate a higher $\mathrm{Cd}^{2+}$ influx at the root tip region, even when cadmium acquisition could be achieved through the entire root utilizing metal transporters. Direct xylem loading due to the absence of the Casparian band and higher expression of transport systems associated with Cd uptake located close to the root tip have been related to this phenomenon (Piñeros et al. 1998; Laporte et al. 2013; Chen et al. 2018). Thus, the root apex could be the main site prone to suffering the toxic effects of metal ions.

In this study, the impact of $\mathrm{Cd}$ on nutrient composition, redox balance, and phytohormone profile of embryonic maize roots was analyzed, distinguishing between the first $5 \mathrm{~mm}$ from the root tip, considering the root apex (Ap), and the remaining root tissue (Rt). Because plants are still under a chemoheterotrophic lifestyle at the pre-emergence stage, our analysis leaves aside the well-known effects of cadmium on photosynthesis.

\section{Materials and methods}

\section{Plant material and growing conditions}

Maize seeds (Zea mays L. cv 2741MGRR2 were kindly provided by DON MARIO Semillas, Buenos Aires, Argentina) were imbibed and germinated on filter paper in a plastic box containing deionized water for $72 \mathrm{~h}$. Then, uniformly developed seedlings with primary roots of approximately $1.5 \mathrm{~cm}$ length were carefully transferred to a hydroponic system containing $250 \mathrm{~mL}$ of diluted (1/10) Hoagland's nutrient solution (Hoagland and Aron 1950) without (control, C) or with 50 or $100 \mu \mathrm{M} \mathrm{CdCl}_{2} ; 30$ seedlings were distributed in each container. These environmentally relevant $\mathrm{Cd}$ concentrations were selected based on previous reports (Adhikari et al. 2018; Liu et al. 2019; Singh et al. 2019). Cd speciation was calculated using Visual MINTEQ version 3.1 (J P Gustafsson, KTH, Sweden). In the nutrient solution containing $100 \mu \mathrm{M}$ of $\mathrm{Cd}$, about $88 \%$ was in $\mathrm{Cd}^{2+}$ form, which appears to be the most phytoavailable form. Plants were grown in a controlled climate room at $24 \pm 2{ }^{\circ} \mathrm{C}$, with $50 \%$ relative humidity. All the experiments were carried out under darkness to mimic soil conditions during germination and post-germinative growth. After $72 \mathrm{~h}$ of treatment, roots were gently washed with distilled water. The tissue collected from each container was considered a biological replicate. Root length, fresh weight (FW), and dry weight (DW, determined after drying the roots at $80^{\circ} \mathrm{C}$ until constant weight), were measured. Additionally, dried root powder was used 
to determine $\mathrm{Cd}$ and nutrient content. Determinations were performed in parallel using root apical segments obtained from the first $5 \mathrm{~mm}$ from the tip (Ap) or the remaining root tissue (Rt).

\section{Nutrient composition of maize roots}

Elemental analysis was performed at the INQUISAL Spectrometry Core Facility, Universidad Nacional de San Luis (UNSL-CONICET). Briefly, dried root powder $(50 \mathrm{mg})$ was homogenized in $1 \mathrm{~mL}$ of $65 \%(\mathrm{v} / \mathrm{v}) \mathrm{HNO}_{3}$ in an ultrasonic bath for $30 \mathrm{~s}$. Then, $0.5 \mathrm{~mL}$ of $\mathrm{H}_{2} \mathrm{O}_{2}$ was added, and the mixture was incubated for $1 \mathrm{~h}$ at $60{ }^{\circ} \mathrm{C}$ in a thermostatic bath (Pequerul et al. 1993). After diluting the samples with ultrapure water, inductively coupled plasma mass spectrometry (ICP-MS) (Perkin Elmer Elan DRC) was used to estimate $\mathrm{Cd}, \mathrm{Cu}, \mathrm{Ca}, \mathrm{Fe}, \mathrm{K}, \mathrm{Mg}, \mathrm{Mn}, \mathrm{P}, \mathrm{S}$, and $\mathrm{Zn}$ content.

\section{Enzymatic and non-enzymatic antioxidants}

Protein extracts were prepared from $0.1 \mathrm{~g}$ of fresh tissue homogenized in $1 \mathrm{~mL}$ of $50 \mathrm{mM}$ phosphate buffer $(\mathrm{pH}$ 7.4) containing $1 \mathrm{mM}$ EDTA and $0.5 \%(\mathrm{v} / \mathrm{v})$ Triton X-100, at $4{ }^{\circ} \mathrm{C}$. The homogenates obtained were centrifuged at $13,000 \mathrm{~g}$ for $30 \mathrm{~min}$ at $4{ }^{\circ} \mathrm{C}$, and the supernatants were used for the assays. Protein content was estimated according to Bradford (1976).

CAT activity was assayed as described by Aebi (1984) by monitoring the decomposition of $\mathrm{H}_{2} \mathrm{O}_{2}$ at $240 \mathrm{~nm}$; CAT content was calculated using $\mathrm{k}=4.7 \times 10^{-7} \mathrm{M}^{-1} \mathrm{~s}^{-1}$ and expressed in pmol mg-1 protein. The activity of guaiacol peroxidase (GPX, EC 1.11.1.7) and ascorbate peroxidase (APX) was measured as described previously (Nakano and Asada 1981). One unit of GPOX was defined as the amount of tetraguaiacol produced (mmol) per min, and one unit of APOX was defined as mmol of oxidized ascorbate per min.

Ascorbate (ASC) and dehydroascorbate (DHA) were determined as described by Law et al. (1983). Extracts were obtained by homogenizing $0.1 \mathrm{~g}$ of root tissue in $1 \mathrm{~mL}$ of $0.1 \mathrm{~N} \mathrm{HCl}$. After centrifugation $\left(13,000 \mathrm{~g}, 30 \mathrm{~min}\right.$, at $\left.4{ }^{\circ} \mathrm{C}\right)$, the supernatants were used for the assays. A standard curve of commercial ASC was used for calibration. To determine GSH, $20-\mu \mathrm{L}$ samples were derivatized with $180 \mu \mathrm{L}$ of $1.3 \mathrm{mM}$ o-phthaldialdehyde (OPA) in borate buffer $(0.4 \mathrm{M}$, $\mathrm{pH}$ 9.7) at room temperature (Robyt and White 1990), and the fluorescence was measured at $455 \mathrm{~nm}$ ( $\lambda$ excitation, $340 \mathrm{~nm}$ ). A standard curve for the determination of GSH was prepared and measured.

\section{Histochemical detection of ROS accumulation}

Superoxide anion production was detected using the nitroblue tetrazolium (NBT) assay. Roots were immersed in
$10 \mathrm{mM}$ Tris-HCl buffer (pH 7.0) containing $1 \mathrm{mM}$ NBT and incubated under light for $30 \mathrm{~min}$. Pale yellow NBT reacts with $\mathrm{O}_{2}{ }^{-}$, forming dark blue insoluble formazan deposits. For $\mathrm{H}_{2} \mathrm{O}_{2}$ detection, roots were incubated for $45 \mathrm{~min}$ with $1 \mathrm{mg} \mathrm{mL}^{-1}$ of 3,3'-diaminobenzidine- $\mathrm{HCl}$ (DAB). $\mathrm{H}_{2} \mathrm{O}_{2}$ presence was visualized as reddish-brown-stained regions due to DAB polymerization.

\section{Quantitative dot blot analysis of carbonylated proteins}

Protein extracts were prepared by homogenizing $0.1 \mathrm{~g}$ of root tissue in $0.5 \mathrm{~mL}$ of loading buffer $(60 \mathrm{mM}$ Tris- $\mathrm{HCl}$ (pH 6.8), 5\% (v/v) $\beta$-mercaptoethanol). After centrifugation at $26,000 \mathrm{~g}$ for $15 \mathrm{~min}$ at $4^{\circ} \mathrm{C}$ and protein derivatization with 2,4-dinitrophenylhydrazine (2,4-DNPH) dot blot analysis was performed as described by Weher and Levine (2012). Membranes were photographed and then analyzed using Gel-Pro software, and the amount of oxidized proteins was expressed as arbitrary units (assuming control value equal to 100 units), based on the absolute integrated optical density of each dot.

\section{Proteasome activities}

Proteasome activity in root tissue was determined as described by Kim et al. (2003). Protein extracts were prepared in $135 \mathrm{mM}$ Tris-acetate buffer (pH 7.5) containing $12.5 \mathrm{mM} \mathrm{KCl}, 80 \mu \mathrm{M}$ EGTA, $6.25 \mathrm{mM}$ 2-mercaptoethanol, and $0.17 \%$ (w/v) octyl- $\beta$-D-glucopyranoside. After homogenizing $100 \mathrm{mg}$ of root tissue (Ap or Rt) in $0.5 \mathrm{~mL}$ buffer, the extracts were centrifuged at $6,400 \mathrm{~g}$ for $30 \mathrm{~min}$ at $4{ }^{\circ} \mathrm{C}$, and the supernatants were further used to determine chymotrypsin-like (Q), trypsin-like (T), and peptidyl glutamyl peptide hydrolase (PGPH) activities (Matayoshi et al. 2020). Due to the extraction buffer interference with the Bradford assay, the protein content was determined using the Lowry method (1951).

\section{Plant hormone analysis}

Hormone extraction and analysis were conducted as described in Durgbanshi et al. (2005), with few modifications (Matayoshi et al. 2020). In brief, for gibberellins (GAs), abscisic acid (ABA), jasmonic acid (JA), JAisoleucine conjugate (JA-Ile), indole-3-acetic acid (IAA), and salicylic acid (SA) extraction, $0.1 \mathrm{~g}$ of ground frozen root tissue was extracted in $2 \mathrm{~mL}$ of ultrapure water, after spiking with $25 \mu \mathrm{L}$ of a solution containing $1 \mathrm{mg} \mathrm{L}^{-1}$ of $\left[{ }^{2} \mathrm{H}\right]-\mathrm{GA} 7,\left[{ }^{2} \mathrm{H}_{6}\right]-\mathrm{ABA}$, DHJA, and $\left[{ }^{13} \mathrm{C}_{6}\right]-\mathrm{SA}$, and $0.1 \mathrm{mg}$ $\mathrm{L}^{-1}$ of $\left[{ }^{2} \mathrm{H}_{2}\right]$-IAA in a ball mill (MillMix20, Domel, Železniki, Slovenija). After centrifugation at $4,700 \mathrm{~g}$ for $10 \mathrm{~min}\left(4^{\circ} \mathrm{C}\right)$, the supernatants were recovered, and the $\mathrm{pH}$ 
was adjusted to 3 with $30 \%$ acetic acid. All extracts were partitioned twice against $2 \mathrm{~mL}$ of diethyl ether, and then the organic layer was recovered and evaporated under vacuum in a centrifuge concentrator (Speed Vac, Jouan, Saint Herblain Cedex, France). Once dried, the residue was resuspended in $500 \mu \mathrm{L}$ of a 10:90 methanol:water solution by gentle sonication. The resulting solution was filtered through $0.22-\mu \mathrm{m}$ polytetrafluoroethylene membrane syringe filters (Albet S.A., Barcelona, Spain) and directly injected into an ultra-performance liquid chromatography system (Acquity SDS, Waters Corp., Milford, MA, USA, or Waters Alliance 2695, Waters Corp.). Chromatographic separations were performed on a $\mathrm{C} 18$ reversed-phase column (Gravity, $50 \times 2.1 \mathrm{~mm} 1.8-\mu \mathrm{m}$ particle size, Macherey-Nagel GmbH, Germany) using a methanol:water (both supplemented with $0.1 \%$ acetic acid) gradient at a flow rate of $300 \mu \mathrm{L} \mathrm{min}{ }^{-1}$. Compounds were quantified using a triple quadrupole mass spectrometer (Micromass, Manchester, UK) connected online to the output of the column through an orthogonal Z-spray electrospray ion source. The spectrometer was operated in negative ionization electrospray mode, and plant hormones were detected according to their specific transitions using a multi-residue mass spectrometric method. Metabolites were monitored at m/z: $\mathrm{SA}_{2} 137>93,{ }^{13} \mathrm{C}_{6}$-SA $143>99$, IAA $174>130$, IAA-d 2 176>132, JA 209>59, DHJA $211>59$, ABA-d 6 269>159, ABA $263>153$, JAIle $322>130$, GA3 345>143, GA4 331>213, GA7- $\mathrm{d}_{2}$ $331>225$, GA7 329>223, GA20 331 > 287. All data were acquired and processed using MassLynx v4.1 software. Relative quantification was achieved by comparing the areas of the different samples.

\section{Statistical analysis}

Each box contained 30 seeds from which $0.1 \mathrm{~g}$ of tissue was collected and considered a biological replicate. Tables and figures show means \pm SEM of three or five independent experiments, with three biological replicates per treatment. Differences among treatments were analyzed by one-way ANOVA, taking $p<0.05$ as significant, followed by Tukey's multiple comparison test.

\section{Results and discussion}

\section{Cadmium accumulation reduced maize root growth and modified root nutrient composition}

The presence of $\mathrm{Cd}$ in the hydroponic solution significantly reduced maize root growth by about $70 \%$ in length and $45 \%$ in biomass (Table 1, Supplemental Fig. 1), in line with previous reports (Xu et al. 2014; Anjum et al. 2016b; $\mathrm{Li}$ et al. 2020a), and $\mathrm{Cd}$ accumulation in maize root was
Table 1 Effect of $\mathrm{Cd}$ on root length and biomass. Maize seedlings were grown in a hydroponic system containing diluted (1/10) Hoagland's nutrient solution without (control, C) or with 50 and $100 \mu \mathrm{M}$ of $\mathrm{CdCl}_{2}$, and root length, fresh weight (FW), and dry weight (DW) were determined $72 \mathrm{~h}$ later

\begin{tabular}{lccc}
\hline & Control & $\mu \mathrm{M} \mathrm{CdCl}_{2}$ & \\
\cline { 3 - 4 } & & 50 & 100 \\
\hline Length $(\mathrm{cm})$ & $8.0 \pm 1.2^{\mathrm{a}}$ & $2.7 \pm 0.3^{\mathrm{b}}$ & $2.4 \pm 0.7^{\mathrm{b}}$ \\
FW & $558 \pm 79^{\mathrm{a}}$ & $269 \pm 65^{\mathrm{b}}$ & $337 \pm 52^{\mathrm{b}}$ \\
DW & $38 \pm 12^{\mathrm{a}}$ & $17 \pm 6^{\mathrm{b}}$ & $17 \pm 6^{\mathrm{b}}$ \\
\hline
\end{tabular}

Data are expressed in $\mathrm{mg} / 10$ seedlings; means \pm SEM of five independent experiments, with three biological replicates per treatment, are shown. Different letters within rows indicate significant differences $(p<0.05)$, according to the Tukey's multiple range test

dose-dependent (Table 2). However, a similar degree of growth impairment was observed at both $\mathrm{Cd}$ concentrations tested. Laboratory soil-less systems abolish the complex physicochemical interactions that take place under natural field conditions and may alter nutrient and pollutant bioavailability. Among the soil properties that govern $\mathrm{Cd}$ diffusion flux towards the root surface, soil $\mathrm{pH}$, clay content, metal oxides, cation exchange capacity, organic matter content, and $\mathrm{Ca}^{2+}$ concentration have been reported, and also total Cd content impacts on Cd uptake (Liu et al. 2015a; Lin et al. 2016; Yi et al. 2020).

Plants have not developed a specialized uptake system for cadmium because this element has no biological function. Nevertheless, this metal can be easily taken up by plant roots through membrane transporters of essential nutrients (Sterckeman and Thomine 2020). Current evidence indicates that Cd root symplastic influx in maize is controlled by high- and low-affinity transport systems (Redjala et al. 2009, 2010). Furthermore, cadmium can be strongly adsorbed on the maize cell wall, resulting in a large amount of $\mathrm{Cd}^{2+}$ retained in the root apoplast (Redjala et al. 2009).

As Table 2 shows, $\mathrm{Cd}$ accumulation in emerging maize roots resulted in significant decreases in $\mathrm{Ca}, \mathrm{Fe}, \mathrm{Mg}$, and $\mathrm{Mn}$ contents. A reduction of $48 \%$ and $68 \%$ in Ca level was determined for 50 and $100 \mu \mathrm{M} \mathrm{Cd}$, respectively. For both Cd concentrations assayed, the reduction in $\mathrm{Mg}$ level was close to $60 \%$, and similar decreases of about $38 \%$ were detected for $\mathrm{Fe}$ and $\mathrm{Mn}$. Moreover, $\mathrm{Zn}$ was significantly incremented by $16 \%$ over the control exposed to $50 \mu \mathrm{M} \mathrm{Cd}$, and $\mathrm{Cu}$ content doubled that of the control in the seedling roots subjected to $100 \mu \mathrm{M} \mathrm{Cd}$.

Change in nutrient absorption/distribution patterns is one of the most recognized cadmium harmful effects and has been mainly attributed to competition with divalent cation transporters (Huang et al. 2020). Ca and Mg (typically the most abundant divalent cations in plants) reductions could have affected normal growth and development. 

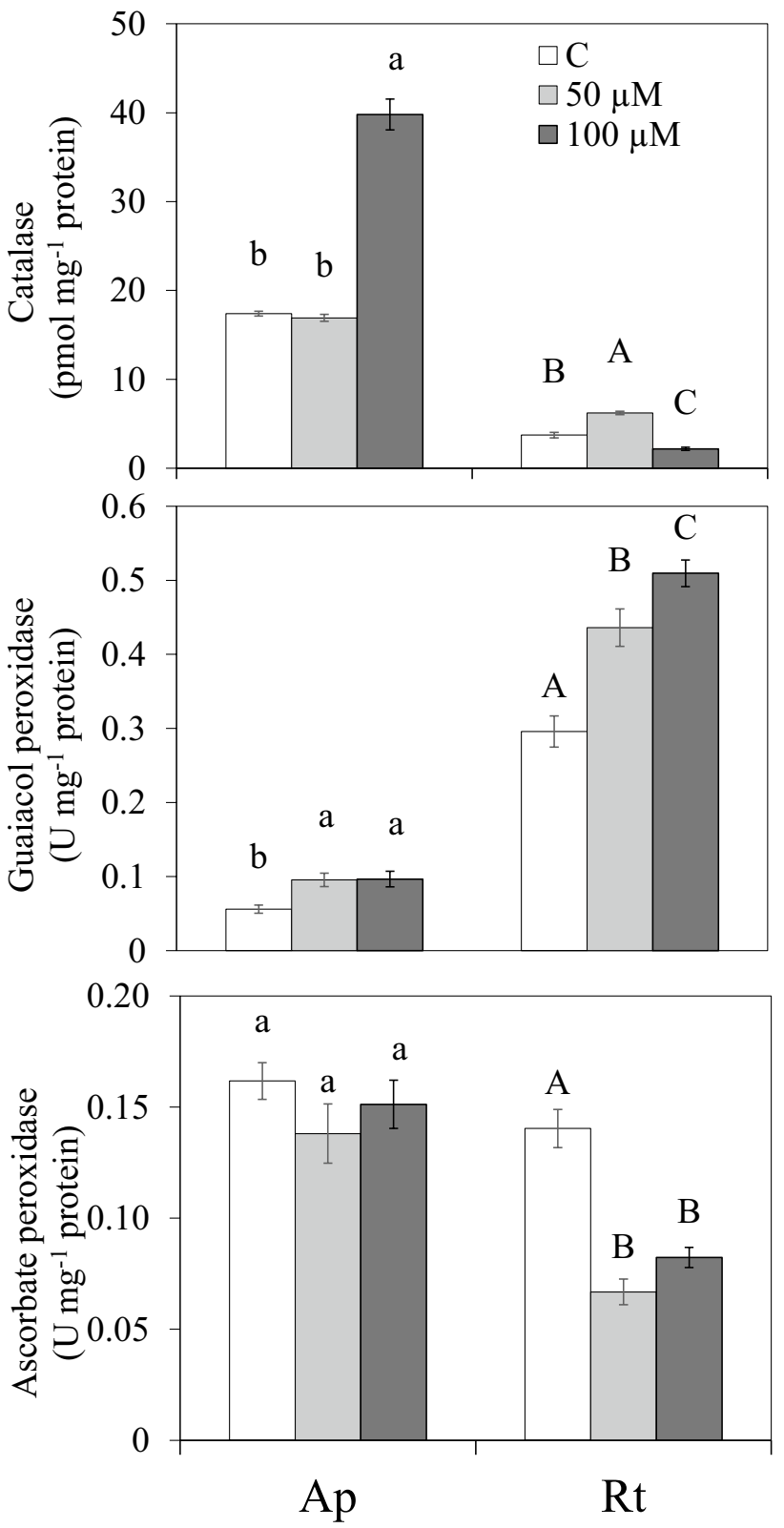

Fig. 1 Effect of $\mathrm{Cd}$ on peroxidase activities. Maize seedlings were subjected to hydroponic culture without (control, C) or with 50 and $100 \mu \mathrm{M}$ of $\mathrm{CdCl}_{2}$ for $72 \mathrm{~h}$. Determinations were performed on extracts obtained from the root apex (Ap) and the remaining root tissue (Rt). Data are representative of five independent experiments with three replicates. At least three technical replicates of each protein extract were used for these determinations. Bars represent means \pm SEM of five independent experiments, with three biological replicates per treatment. Different letters indicate significant differences $(p<0.05)$, according to the Tukey's multiple range test

In this sense, it has been pointed out that growth restriction under $\mathrm{Cd}$ stress would be a nutrient deficiency symptom and the result of homeostatic balance loss between these cations (Tang and Luan 2017; Thor 2019; Kleczkowski and Igamberdiev 2021). Similarly, Cd reduces Fe and Mn contents in maize root. According to several reports, Cd shares similar plant entry routes with these relevant nutrients, so that the decreases found can be the outcome of Cd competition with $\mathrm{Fe}$ and $\mathrm{Mn}$ transporters (Thomine et al. 2000; Wu et al. 2016; Chen et al. 2017b; Chang et al. 2020). Furthermore, it has been demonstrated that the external addition of $\mathrm{Ca}, \mathrm{Mg}$, $\mathrm{Fe}$, or $\mathrm{Mn}$ to the nutrient solution restricts $\mathrm{Cd}$ uptake and translocation, resulting in alleviation of Cd stress (Pal'oveBalang et al. 2006; Sterckeman et al. 2011; Liu et al. 2013; Kudo et al. 2015; Rahman et al. 2016; Huang et al. 2017; Chen et al. 2017a; Hussain et al. 2020).

A complex interaction between $\mathrm{Cd}$ and $\mathrm{Zn}$ has previously been documented, proposing that $\mathrm{Zn}$ uptake/translocation would increase in the presence of Cd (Nan et al. 2002). Moreover, it was demonstrated that the induction of several genes belonging to the ZIP family-a group of proteins that mediate $\mathrm{Zn}$ and $\mathrm{Cd}$ transport-depends on the $\mathrm{Zn}: \mathrm{Cd}$ ratio in the growing medium (Barabasz et al. 2016; Palusińska et al. 2020).

$\mathrm{Cu}$ increase and $\mathrm{Mn}$ decrease could account for cell redox homeostasis disruption under $\mathrm{Cd}$ stress. $\mathrm{Cu}$ is a redox-active metal and $\mathrm{Mn}$, in addition to having free radical scavenging capacity (Coassin et al. 1992), acts as a cofactor of an important enzymatic antioxidant, superoxide dismutase (Mn-SOD); $\mathrm{Ca}$ is also a signaling messenger intimately interconnected with ROS (Mazars et al. 2010; Steinhorst and Kudla 2013). Thus, the nutrient imbalance could be part of the indirect mechanisms by which $\mathrm{Cd}$ induces oxidative stress in maize roots.

\section{Cadmium differentially affected peroxidase activities along the root and disrupted ascorbate homeostasis}

In maize seminal root, CAT and APX activities were mostly localized in the root tip (Ap), while GPX activity was predominantly detected in the remaining tissue (Rt) (Fig. 1). Among peroxidases, CAT catalyzes the dismutation of $\mathrm{H}_{2} \mathrm{O}_{2}$ in the absence of electron donors. Its activity is largely found in subcellular compartments with $\mathrm{H}_{2} \mathrm{O}_{2}$ generation, such as peroxisomes, and also in mitochondria, chloroplasts, and the cytosol (Sharma and Ahmad 2014). CAT activity significantly increased in the Ap under $100 \mu \mathrm{M} \mathrm{Cd}^{2+}$ (130\% over the control); however, in the Rt, CAT activity significantly increased by $67 \%$ under $50 \mu \mathrm{M}$ $\mathrm{Cd}^{2+}$ and significantly decreased by $42 \%$ under $100 \mu \mathrm{M}$ $\mathrm{Cd}^{2+}$ compared to the control. An increase in CAT activity may be interpreted as a cell-protective strategy against the detrimental effect of $\mathrm{H}_{2} \mathrm{O}_{2}$. On the contrary, a decrease in CAT activity deprives cells of their normal antioxidant capacity and results in oxidative stress. Catalase inactivation by metals has been associated with the oxidation of 
Table 2 Effect of $\mathrm{Cd}$ on root chemical composition. Maize seedlings were grown in a hydroponic system containing diluted (1/10) Hoagland's nutrient solution without (control, C) or with 50 and
$100 \mu \mathrm{M}$ of $\mathrm{CdCl}_{2}$. After $72 \mathrm{~h}$ of treatment, roots were harvested and used for analytical determinations. Element concentrations are expressed in $\mathrm{mg} \mathrm{kg}^{-1}$ of dry weight

\begin{tabular}{|c|c|c|c|c|c|c|c|c|c|c|}
\hline & $\mathrm{Cd}$ & $\mathrm{Cu}$ & $\mathrm{Ca}$ & $\mathrm{Fe}$ & $\mathrm{K}$ & $\mathrm{Mg}$ & $\mathrm{Mn}$ & $\mathrm{P}$ & $S$ & $\mathrm{Zn}$ \\
\hline C & $18 \pm 9^{c}$ & $30 \pm 10^{\mathrm{b}}$ & $2135 \pm 326^{\mathrm{a}}$ & $79 \pm 09^{\mathrm{a}}$ & $15,367 \pm 1436^{\mathrm{a}}$ & $1372 \pm 460^{\mathrm{a}}$ & $8 \pm 1^{\mathrm{a}}$ & $9871 \pm 420^{\mathrm{a}}$ & $1688 \pm 398^{\mathrm{a}}$ & $59 \pm 1^{\mathrm{b}}$ \\
\hline $50 \mu \mathrm{M}$ & $1264 \pm 47^{b}$ & $35 \pm 4^{b}$ & $1103 \pm 94^{\mathrm{b}}$ & $49 \pm 3^{b}$ & $19,474 \pm 1611^{\mathrm{a}}$ & $525 \pm 9^{b}$ & $5 \pm 1^{\mathrm{b}}$ & $10,868 \pm 165^{\mathrm{a}}$ & $1723 \pm 124^{a}$ & $69 \pm 4^{a}$ \\
\hline $100 \mu \mathrm{M}$ & $1933 \pm 158^{a}$ & $73 \pm 9^{a}$ & $700 \pm 49^{b}$ & $50 \pm 2^{\mathrm{b}}$ & $17,927 \pm 178^{\mathrm{a}}$ & $654 \pm 12^{\mathrm{b}}$ & $5 \pm 1^{\mathrm{b}}$ & $9299 \pm 268^{a}$ & $1644 \pm 196^{a}$ & $55 \pm 2^{\mathrm{b}}$ \\
\hline
\end{tabular}

Data represent mean \pm SEM of three independent experiments, with three biological replicates per treatment. Different letters within columns indicate significant differences $(p<0.05)$, according to the Tukey's multiple range test

the protein structure (Pena et al. 2011) and the suppression of CAT gene expression (Ye et al. 2014).

To counteract excessive $\mathrm{H}_{2} \mathrm{O}_{2}$ formation in plant tissues, non-specific peroxidases acting on one- or two-electron donors (including phenolic compounds such as guaiacol) are usually induced. In plants, GPX activity is mainly located in vacuoles and cell walls but not in organelles (Asada 1992). Under both concentrations, Cd significantly increased GPX activity by about $70 \%$ in the Ap, while in the Rt, significant increases of $47 \%$ and $72 \%$ in the control with 50 and $100 \mu \mathrm{M} \mathrm{Cd}^{2+}$ respectively, were recorded (Fig. 1). GPX activity rise during $\mathrm{Cd}$ stress would be involved not only in the control of $\mathrm{H}_{2} \mathrm{O}_{2}$ levels but also in the modulation of plant growth and development through the control of hormonal and cell wall metabolism (Jouili et al. 2011).

Ascorbate peroxidase reduces $\mathrm{H}_{2} \mathrm{O}_{2}$ to $\mathrm{H}_{2} \mathrm{O}$ using ascorbate as the specific electron donor. Different APX isoforms are located in chloroplasts, cytosol, mitochondria, and peroxisomes, as well as in the apoplastic space (Gill and Tuteja 2010; Hasanuzzaman et al. 2019). In maize root apex, APX activity was not affected by Cd treatment, in line with previous observations in barley root tips (Bocova et al. 2012); however, the activity of this enzyme was particularly impaired in the Rt, dropping by almost half under both $\mathrm{Cd}$ concentrations (Fig. 1). Because of a higher APX affinity for $\mathrm{H}_{2} \mathrm{O}_{2}$ than CAT and GPX, it has been suggested that this enzyme has a more crucial role in the scavenging of ROS during abiotic stress (Sofo et al. 2015; Anjum et al. 2016a).
In both root portions, total ASC (ASC plus DHA) levels significantly augmented under $\mathrm{Cd}$ treatment due to a pronounced rise in DHA content, resulting, at the same time, in the reduction of ASC/DHA ratio (Table 3). Moreover, the metal significantly increased GSH content in the Rt (twofold increase), but was significantly reduced in the Ap under $100 \mu \mathrm{M} \mathrm{Cd}$ (20\% of control value) (Table 3). Maintaining a high intracellular GSH level is vital to mitigate Cd-induced oxidative stress injuries in plants (Gallego et al. 2005; Mostofa et al. 2015). The decline in redox AsA/DHA and GSH/ GSSG ratios suggests that $\mathrm{Cd}$ altered the adequate functioning of the ASC-GSH cycle (Mostafa et al. 2019). The role of these compounds in the alleviation of $\mathrm{Cd}$ toxicity was previously demonstrated, through the exogenous application of ASC and GSH to maize ( $\mathrm{Li}$ et al. 2017; Zhang et al. 2019). Although $\mathrm{Cd}$ is a non-redox metal, unable to participate in Fenton-type reactions, the redox imbalance induced by this metal resulted in $\mathrm{O}_{2}^{-}$and $\mathrm{H}_{2} \mathrm{O}_{2}$ accumulation, mainly in root apexes (Fig. 2). ROS accumulation triggered by $\mathrm{Cd}$ in maize root is in agreement with previous findings (Adhikari et al. 2018).

\section{Cadmium-induced accumulation of oxidatively damaged proteins was prevented by $20 \mathrm{~S}$ proteasome increased activity}

Protein carbonylation is considered a reliable parameter of oxidative stress (Shulaev and Oliver 2006). Additionally, the accumulation of oxidized proteins reflects the balance
Table 3 Effect of Cd on ascorbate (ASC), dehydroascorbate (DHA) and glutathione $(\mathrm{GSH})$ content. Maize seedlings were grown in a hydroponic system containing diluted (1/10) Hoagland's nutrient solution without (control, C) or with 50 and $100 \mu \mathrm{M}$ of $\mathrm{CdCl}_{2}$ for $72 \mathrm{~h}$. ASC and DHA concentrations are expressed in $\mathrm{nmol} \mathrm{g}^{-1}$ of fresh weight (FW); GSH concentration is expressed in $\mu \mathrm{mol} \mathrm{g}^{-1} \mathrm{FW}$

\begin{tabular}{|c|c|c|c|c|c|c|c|c|}
\hline & \multicolumn{4}{|l|}{ Ap } & \multicolumn{4}{|l|}{ Rt } \\
\hline & ASC & DHA & ASC/DHA & GSH & ASC & DHA & ASC/DHA & GSH \\
\hline $\mathrm{C}$ & $218 \pm 10^{\mathrm{a}}$ & $475 \pm 31^{\mathrm{c}}$ & 0.5 & $0.17 \pm 0.01^{b}$ & $915 \pm 50^{\mathrm{A}}$ & $310 \pm 60^{\mathrm{B}}$ & 2.9 & $0.20 \pm 0.02^{\mathrm{B}}$ \\
\hline $50 \mu \mathrm{M}$ & $248 \pm 5^{\mathrm{a}}$ & $2265 \pm 81^{\mathrm{a}}$ & 0.1 & $0.20 \pm 0.01^{\mathrm{a}}$ & $1090 \pm 20^{\mathrm{A}}$ & $590 \pm 40^{\mathrm{B}}$ & 1.8 & $0.42 \pm 0.02^{\mathrm{A}}$ \\
\hline $100 \mu \mathrm{M}$ & $151 \pm 5^{\mathrm{b}}$ & $1600 \pm 69^{b}$ & 0.1 & $0.14 \pm 0.01^{\mathrm{c}}$ & $1010 \pm 60^{\mathrm{A}}$ & $1030 \pm 120^{\mathrm{A}}$ & 1.0 & $0.46 \pm 0.01^{\mathrm{A}}$ \\
\hline
\end{tabular}

Data represent means \pm SEM of five independent experiments, with three biological replicates per treatment. Different letters within columns indicate significant differences $(p<0.05)$, according to the Tukey's multiple range test 


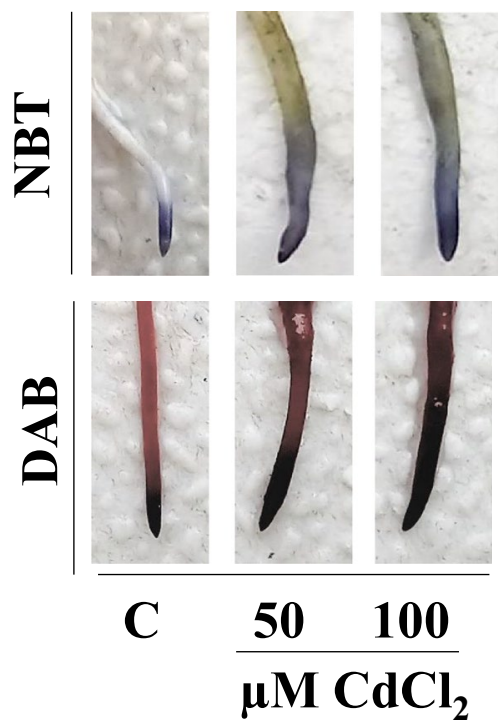

Fig. 2 In situ detection of superoxide anion and hydrogen peroxide in maize roots using nitroblue tetrazolium (NBT) and 3,3'-diaminobenzidine (DAB) staining method, respectively. Maize seedlings were subjected to hydroponic culture without (control, C) or with 50 and $100 \mu \mathrm{M}$ of $\mathrm{CdCl}_{2}$ for $72 \mathrm{~h}$. The images shown are representative of five independent experiments

between their production and degradation, mainly by the $20 \mathrm{~S}$ proteasome activity. Under our experimental conditions, only $100 \mu \mathrm{M} \mathrm{Cd}$ significantly incremented protein carbonyl group content along the whole root (Fig. 3A).

A time-dependent analysis of three peptidase activities was assayed for the $50 \mu \mathrm{M} \mathrm{Cd}$ treatment. As shown in Fig. 3B and C, the metal incremented 20S peptide-hydrolyzing activities. At $72 \mathrm{~h}$, all of them were significantly increased in the Ap, and also T and Q in the Rt. Thus, the absence of carbonylated protein accumulation in maize roots subjected to $50 \mu \mathrm{M}$ treatment could be attributed to the increase in the activity of the $20 \mathrm{~S}$ proteasome, similarly as previously described (Pena et al. 2007).

\section{Cadmium altered hormonal root homeostasis}

Cadmium significantly enhanced IAA and ABA levels in the entire root tissue, whereas SA content significantly increased only in the Rt portion (Table 4). IAA increments by $\mathrm{Cd}$ in rice roots were related to the overexpression of the biosynthetic genes OsASA2 and OsYUCCA1 (Ronzan et al. 2019). Furthermore, it has been described that $\mathrm{Cd}$ not only affects IAA content but also its distribution, metabolism, and transport (Chmielowska-Bak et al. 2014), suggesting an eventual switch to an alternative morphogenic root program to counteract metal stress (Hu et al. 2013; Fattorini et al. 2017; Piacentini et al. 2020). Numerous reports also indicate that the exogenous application of
IAA, as well as the IAA precursor indole-3-butyric acid (IBA), reduced Cd toxicity in plants (Agami and Mohamed 2013; Li et al. 2020b; Zhang et al. 2020; Zhou et al. 2020; Piacentini et al. 2020; Demecsová et al. 2020). However, further information is needed to know whether the endogenous IAA levels reached in maize root during $\mathrm{Cd}$ stress can induce a similar effect compared to that observed when IAA is exogenously added.

In plants, $\mathrm{ABA}$ is recognized as a modulator of adaptive abiotic stress responses (Cutler et al. 2010) and a key player in alleviating heavy metal stress (Hu et al. 2020). Hsu and Kao (2003) reported a close relationship between endogenous $\mathrm{ABA}$ content and $\mathrm{Cd}$ tolerance in rice seedlings. It has also described that exogenous $\mathrm{ABA}$ application would partially relieve $\mathrm{Cd}$ toxic effects by increasing GSH and phytochelatin biosynthesis (Chen et al. 2016; Song et al. 2016), as well as restrict Cd uptake and distribution (Han et al. 2016; Shen et al. 2017; Tang et al. 2020).

SA increase in the Rt may be involved as a mechanism to counteract oxidative stress induced by $\mathrm{Cd}$. It has been well established that SA application improves plant acclimation to $\mathrm{Cd}$ excess by reducing the metal uptake and/or promoting plant antioxidant capacity (Popova et al. 2009; Hayat et al. 2010; Agami and Mohamed 2013; Shakirova et al. 2016; Guo 2019). In accordance, an Arabidopsis SA-deficient mutant resulted in negative effects on Cd tolerance, mainly due to the lowered GSH status (Guo et al. 2016).

Cadmium at $100 \mu \mathrm{M}$ significantly increased the root concentration of GA20 (Table 4), the precursor of the active form 13-hydroxylated GA3. Interestingly, the total root content of GA3 remained similar to the control at this $\mathrm{Cd}$ concentration but significantly decreased in the Ap and increased in the Rt at $50 \mu \mathrm{M} \mathrm{Cd}$. On the other hand, the contents of non-13-hydroxylated GA7 and GA4 were significantly reduced under $\mathrm{Cd}$ treatments. A similar drastic decrease in GA4 content was reported during copper stress (Matayoshi et al. 2020).

The mechanism by which metals affect GA4 homeostasis could involve interference with hormone biosynthesis but also with subsequent gibberellin transformations. Liu et al. (2015b) reported up-regulation of two genes encoding GA2oxidase, a major enzyme for deactivating bioactive gibberellins, in response to $\mathrm{Cd}$ stress.

The presence of $\mathrm{Cd}$ exerted a dramatic effect on the active form JA-Ile, whose concentration was strongly diminished under the metal treatment. JA-Ile is considered the most metabolically active jasmonate (Fonseca et al. 2009), and, although the exogenous application of JA or methyl jasmonate (MJ) has been shown to alleviate Cd-toxic effects in plants (Singh and Shah 2014; Siddiqi and Husen 2019; Lei et al. 2020), little attention has been given to Ile-JA regarding cadmium stress. Kurotani et al. (2015) suggested that deactivation of JA-Ile results in enhanced salt tolerance in 
Fig. 3 Effect of $\mathrm{Cd}$ on oxidative-damaged proteins and proteasome proteolytic activities. Carbonyl group content (A) was determined in root protein extracts obtained from root tips (At) and the remaining root tissue (Rt) of maize seedlings subjected to hydroponic culture without (control) or with 50 and $100 \mu \mathrm{M}$ of $\mathrm{CdCl}_{2}$ for $72 \mathrm{~h}$. Proteins were derivatized with DNPH and an analysis was performed by dot blot. Membranes were photographed and analyzed using Gel-Pro software. Quantification of oxidized proteins was based on the absolute integrated optical density (IOD) of each dot and expressed as percentage of the amount present in the control (assuming control equal to $100 \%$ ). Bars represent mean \pm SEM. Proteasome activities in the root tips (B) and the remaining root tissue (C) were determined in maize seedlings subjected to hydroponic culture without (control) or with $50 \mathrm{CdCl}_{2}$ up to $72 \mathrm{~h}$. Trypsin-like, chymotrypsin-like, and peptidyl-glutamyl-peptide hydrolase (PGPH) proteasome activities were measured at three times from the onset of Cd stress using three peptide substrates (Boc-LSYRAMC, AAF-AMC, and Clz-LLE- $\beta$ NA, respectively) of the $20 \mathrm{~S}$ proteasome in the absence or presence of the proteasome inhibitor MG132. Enzymatic activities were normalized for protein concentrations and expressed as percentage of the activity present in the control (assuming control equal to $100 \%$ ). Data are representative of five independent experiments with three replicates. At least three technical replicates of each protein extract were used for each determination. Bars represent mean values \pm SEM. Asterisks indicate significant differences compared to the control $(* p<0.05$, $* * p<0.01$, and $* * * p<0.001$ ), according to the Tukey's multiple range test

rice. It would be of special interest to evaluate the turnover of JA-Ile in the context of Cd stress in future studies.

\section{Conclusion}

Maize seedlings exposed to $\mathrm{Cd}$ arrested root growth, and the entire primary root was found to be involved in redox and hormonal adjustments to trigger and/or to support defense mechanisms to cope with $\mathrm{Cd}$ stress. The integrated analysis of our experimental data shows that $\mathrm{Cd}$ addition decreases the root content of several essential nutrients, disrupts ASC homeostasis, and causes a strong decline in GA4 and JA-Ile levels, along with root growth inhibition. Faced with the incapacity of maintaining ASC homeostasis, CAT and GPX would be alternative enzymatic defense lines for seminal roots to remove ROS excess during Cd stress. Finally, the $20 \mathrm{~S}$ proteasome seems to be a relevant defense component to cope with the oxidative damage generated by cadmium during this early stage of plant development.

Taking into account that dealing with environmental stresses requires a metabolic reorganization that affects plant growth, the data reported in this study provide valuable advances in the biochemical adjustments that integrate the
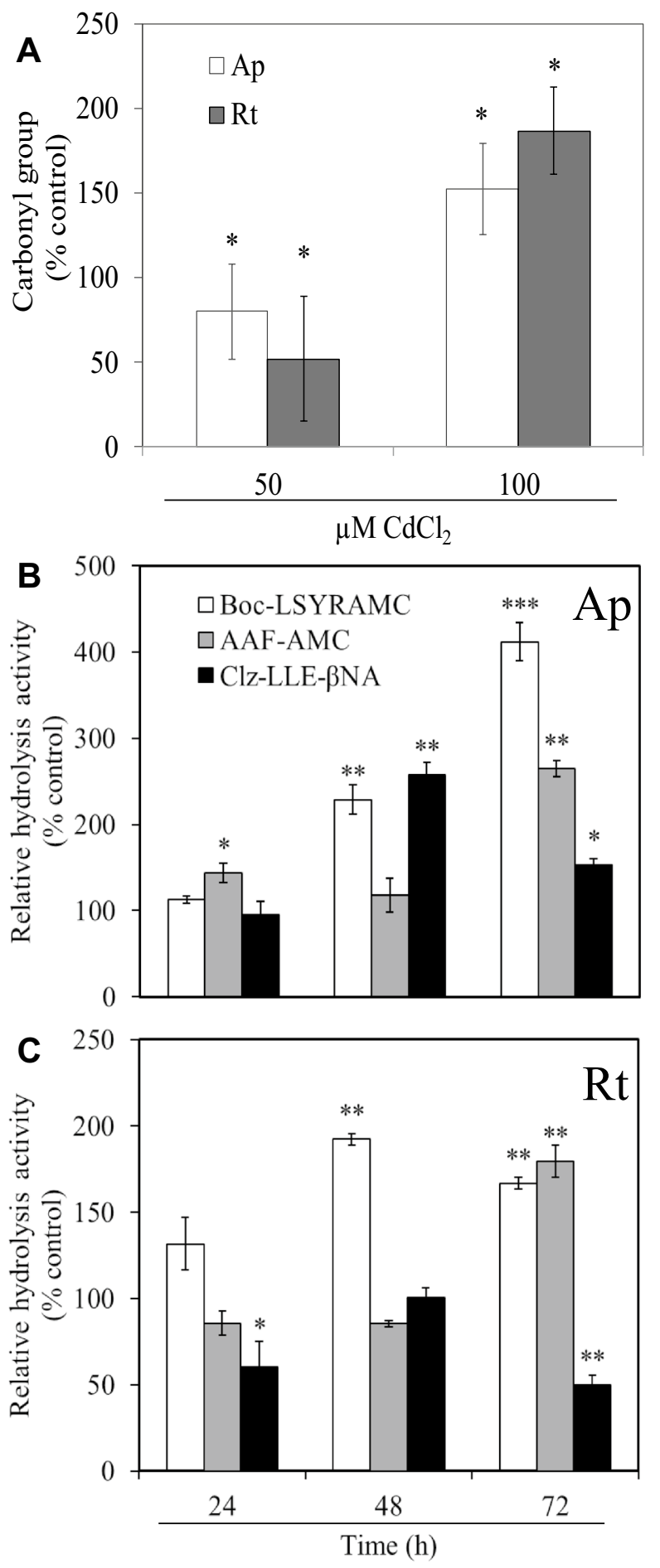

responses of the apex and the remaining maize embryonic roots to $\mathrm{Cd}$ stress. 
Table 4 Effect of Cd on hormone content. Extracts were obtained from root apex (Ap) and the remaining root tissue (Rt) of maize seedlings subjected to hydroponic culture without (control, C) or with 50 and $100 \mu \mathrm{M}$ of $\mathrm{CdCl}_{2}$ for $72 \mathrm{~h}$

\begin{tabular}{|c|c|c|c|c|c|c|}
\hline \multirow{3}{*}{$\begin{array}{l}\text { Hormone } \\
\text { content } \\
\left(\mathrm{ng} \mathrm{g}^{-1} \mathrm{FW}\right)\end{array}$} & \multicolumn{3}{|l|}{ Ap } & \multicolumn{3}{|l|}{ Rt } \\
\hline & \multirow[t]{2}{*}{$\mathrm{C}$} & \multicolumn{2}{|l|}{$\mathrm{CdCl}_{2}(\mu \mathrm{M})$} & \multirow[t]{2}{*}{$\mathrm{C}$} & \multicolumn{2}{|l|}{$\mathrm{CdCl}_{2}(\mu \mathrm{M})$} \\
\hline & & 50 & 100 & & 50 & 100 \\
\hline IAA & $10.8 \pm 1.7^{\mathrm{a}}$ & $13.9 \pm 0.6^{b}$ & $20.5 \pm 0.7^{\mathrm{c}}$ & $8.1 \pm 2.3^{\mathrm{A}}$ & $23.6 \pm 2.6^{\mathrm{B}}$ & $36.3 \pm 5.7^{\mathrm{C}}$ \\
\hline $\mathrm{ABA}$ & $1.94 \pm 0.15^{\mathrm{a}}$ & $5.46 \pm 0.61^{b}$ & $3.49 \pm 0.12^{\mathrm{b}}$ & $1.67 \pm 0.49^{\mathrm{A}}$ & $8.65 \pm 0.34^{\mathrm{B}}$ & $12.51 \pm 0.63^{\mathrm{B}}$ \\
\hline SA & $9.3 \pm 0.2^{\mathrm{a}}$ & $17.3 \pm 1.6^{\mathrm{b}}$ & $5.6 \pm 0.5^{\mathrm{c}}$ & $16.6 \pm 1.7^{\mathrm{A}}$ & $25.6 \pm 1.6^{\mathrm{B}}$ & $25.0 \pm 1.0^{\mathrm{B}}$ \\
\hline GA20 & $3.1 \pm 0.3^{\mathrm{a}}$ & $3.0 \pm 0.3^{\mathrm{a}}$ & $4.9 \pm 0.1^{\mathrm{b}}$ & $2.7 \pm 0.2^{\mathrm{A}}$ & $3.7 \pm 0.6^{\mathrm{A}}$ & $6.4 \pm 0.2^{\mathrm{B}}$ \\
\hline GA7 & $146 \pm 9^{a}$ & $123 \pm 4^{\mathrm{b}}$ & $125 \pm 6^{\mathrm{b}}$ & $146 \pm 4^{\mathrm{A}}$ & $148 \pm 8^{\mathrm{A}}$ & $156 \pm 3^{\mathrm{A}}$ \\
\hline GA3 & $5.1 \pm 0.8^{\mathrm{a}}$ & $3.7 \pm 0.3^{\mathrm{b}}$ & $5.3 \pm 0.3^{\mathrm{a}}$ & $3.3 \pm 0.6^{\mathrm{B}}$ & $5.8 \pm 0.7^{\mathrm{A}}$ & $3.9 \pm 0.7^{\mathrm{B}}$ \\
\hline GA4 & $58.6 \pm 14.3^{\mathrm{a}}$ & $25 \pm 2^{b}$ & $18.2 \pm 2^{\mathrm{c}}$ & $65.7 \pm 10.0^{\mathrm{A}}$ & $38 \pm 10^{\mathrm{B}}$ & $35 \pm 1.8^{\mathrm{B}}$ \\
\hline JA & $61.2 \pm 10.7^{\mathrm{a}}$ & $64.2 \pm 5.8^{\mathrm{a}}$ & $38.4 \pm 2.5^{\mathrm{b}}$ & $82.8 \pm 12.1^{\mathrm{A}}$ & $71.8 \pm 1.9^{\mathrm{A}}$ & $89.3 \pm 8.5^{\mathrm{A}}$ \\
\hline JA-Ile & $47.6 \pm 5.7^{\mathrm{a}}$ & $9.5 \pm 2.8^{\mathrm{b}}$ & $3.7 \pm 0.2^{\mathrm{b}}$ & $57.9 \pm 9.6^{\mathrm{A}}$ & $14.8 \pm 0.3^{\mathrm{B}}$ & $20.9 \pm 3.1^{\mathrm{B}}$ \\
\hline
\end{tabular}

Data represent means \pm SEM of three independent experiments, with three biological replicates per treatment. Values represent means \pm SEM. Different letters within rows indicate significant differences $(p<0.05)$, according to the Dunnett's multiple comparisons test
Supplementary Information The online version contains supplementary material available at https://doi.org/10.1007/s10725-021-00774-w.

Acknowledgements We thank Dr. Myriam S. Zawoznik for her helpful criticism to improve the manuscript. CLM is a Research Fellow at UBA (Argentina). LBP and SMG are CONICET Career Investigators (Argentina). Hormone measurements were performed at Servei Central d'Instrumentació Científica (SCIC) of Universitat Jaume I (Spain).

Funding This work was supported by the Universidad de Buenos Aires (20020170100331BA UBACYT), and by Consejo Nacional de Investigaciones Científicas y Técnicas (PIP 0441).

\section{Declarations}

Conflict of interest The authors have no conflicts of interest to declare that are relevant to the content of this article.

\section{References}

Abendroth L, Elmore RW, Boyer MJ, Marlay SK (2011) Corn growth and development. Iowa State University, Agronomy Extension. PMR 1009

Adhikari S, Ghosh S, Azahar I et al (2018) Sulfate improves cadmium tolerance by limiting cadmium accumulation, modulation of sulfur metabolism and antioxidant defense system in maize. Environ Exp Bot 153:143-162. https://doi.org/10. 1016/j.envexpbot.2018.05.008

Aebi H (1984) Catalase in vitro. Methods Enzymol 105:121-126. https://doi.org/10.1016/S0076-6879(84)05016-3

Agami RA, Mohamed GF (2013) Exogenous treatment with indole3 -acetic acid and salicylic acid alleviates cadmium toxicity in wheat seedlings. Ecotoxicol Environ Saf 94:164-171. https:// doi.org/10.1016/j.ecoenv.2013.04.013

Anjum SA, Tanveer M, Hussain S et al (2015) Cadmium toxicity in maize (Zea mays L.): consequences on antioxidative systems, reactive oxygen species and cadmium accumulation. Environ
Sci Pollut Res 22:17022-17030. https://doi.org/10.1007/ s11356-015-4882-z

Anjum NA, Sharma P, Gill SS et al (2016a) Catalase and ascorbate peroxidase-representative $\mathrm{H}_{2} \mathrm{O}_{2}$-detoxifying heme enzymes in plants. Environ Sci Pollut Res 23:19002-19029. https://doi. org/10.1007/s11356-016-7309-6

Anjum SA, Tanveer M, Hussain S et al (2016b) Osmoregulation and antioxidant production in maize under combined cadmium and arsenic stress. Environ Sci Pollut Res 23:11864-11875. https:// doi.org/10.1007/s11356-016-6382-1

Asada K (1992) Ascorbate peroxidase -A hydrogen peroxide-scavenging enzyme in plants. Physiol Plant 85:235-241. https://doi.org/ 10.1111/j.1399-3054.1992.tb04728.x

Barabasz A, Klimecka M, Kendziorek M et al (2016) The ratio of Zn to Cd supply as a determinant of metal-homeostasis gene expression in tobacco and its modulation by overexpressing the metal exporter AtHMA4. J Exp Bot 67:6201-6214. https://doi.org/10. 1093/jxb/erw389

Bartoli CG, Casalongué CA, Simontacchi M et al (2013) Interactions between hormone and redox signalling pathways in the control of growth and cross tolerance to stress. Environ Exp Bot 94:73-88. https://doi.org/10.1016/j.envexpbot.2012.05.003

Bocova B, Huttova J, Liptakova L et al (2012) Impact of short-term cadmium treatment on catalase and ascorbate peroxidase activities in barley root tips. Biol Plant 56:724-728. https://doi.org/10. 1007/s 10535-012-0129-8

Bradford MM (1976) A rapid and sensitive method for the quantitation of microgram quantities of protein utilizing the principle of protein-dye binding. Anal Biochem 72:248-254. https://doi.org/ 10.1016/0003-2697(76)90527-3

Cai K, Yu Y, Zhang M, Kim K (2019) Concentration, source, and total health risks of cadmium in multiple media in densely populated areas, China. Int J Environ Res Public Health 16:2269. https:// doi.org/10.3390/ijerph16132269

Chang JD, Huang S, Yamaji N et al (2020) OsNRAMP1 transporter contributes to cadmium and manganese uptake in rice. Plant, Cell Environ 43:2476-2491. https://doi.org/10.1111/pce.13843

Chen J, Yang L, Yan X et al (2016) Zinc-finger transcription factor ZAT6 positively regulates cadmium tolerance through the glutathione-dependent pathway in Arabidopsis. Plant Physiol 171:707-719. https://doi.org/10.1104/pp.15.01882 
Chen BC, Wang PJ, Ho PC, Juang KW (2017a) Nonlinear biotic ligand model for assessing alleviation effects of $\mathrm{Ca}, \mathrm{Mg}$, and $\mathrm{K}$ on $\mathrm{Cd}$ toxicity to soybean roots. Ecotoxicology 26:942-955. https://doi. org/10.1007/s10646-017-1823-2

Chen Z, Tang Y-T, Zhou C et al (2017b) Mechanisms of Fe biofortification and mitigation of $\mathrm{Cd}$ accumulation in rice (Oryza sativa L.) grown hydroponically with Fe chelate fertilization. Chemosphere 175:275-285. https://doi.org/10.1016/j.chemosphere. 2017.02.053

Chen X, Ouyang Y, Fan Y et al (2018) The pathway of transmembrane cadmium influx via calcium-permeable channels and its spatial characteristics along rice root. J Exp Bot 69:5279-5291. https://doi.org/10.1093/jxb/ery293

Chmielowska-Bak J, Gzyl J, Rucinska-Sobkowiak R et al (2014) The new insights into cadmium sensing. Front Plant Sci 5:245. https://doi.org/10.3389/fpls.2014.00245

Chumbley CG, Unwin RJ (1982) Cadmium and lead content of vegetable crops grown on land with a history of sewage sludge application. Environ Pollut B 4:231-237. https://doi.org/10. 1016/0143-148X(82)90055-6

Coassin M, Ursini F, Bindoli A (1992) Antioxidant effect of manganese. Arch Biochem Biophys 299:330-333. https://doi.org/10. 1016/0003-9861(92)90282-2

Cutler SR, Rodriguez PL, Finkelstein RR, Abrams SR (2010) Abscisic acid: emergence of a core signaling network. Annu Rev Plant Biol 61:651-679. https://doi.org/10.1146/annurev-arpla nt-042809-112122

Dala-Paula BM, Custódio FB, Knupp EAN et al (2018) Cadmium, copper and lead levels in different cultivars of lettuce and soil from urban agriculture. Environ Pollut 242:383-389. https:// doi.org/10.1016/j.envpol.2018.04.101

De Tullio MC, Jiang K, Feldman LJ (2010) Redox regulation of root apical meristem organization: connecting root development to its environment. Plant Physiol Biochem 48:328-336. https:// doi.org/10.1016/j.plaphy.2009.11.005

Demecsová L, Zelinová V, Liptáková L' et al (2020) Indole-3-butyric acid priming reduced cadmium toxicity in barley root tip via NO generation and enhanced glutathione peroxidase activity. Planta 252:46. https://doi.org/10.1007/s00425-020-03451-w

Dharma-Wardana MWC (2018) Fertilizer usage and cadmium in soils, crops and food. Environ Geochem Health 40:2739-2759. https://doi.org/10.1007/s10653-018-0140-x

Durgbanshi A, Arbona V, Pozo O et al (2005) Simultaneous determination of multiple phytohormones in plant extracts by liquid chromatography-electrospray tandem mass spectrometry. J Agric Food Chem 53:8437-8442. https://doi.org/10.1021/ jf050884b

Fattorini L, Ronzan M, Piacentini D et al (2017) Cadmium and arsenic affect quiescent centre formation and maintenance in Arabidopsis thaliana post-embryonic roots disrupting auxin biosynthesis and transport. Environ Exp Bot 144:37-48. https://doi.org/10.1016/j. envexpbot.2017.10.005

Fonseca S, Chini A, Hamberg M et al (2009) (+)-7-iso-Jasmonoyl-Lisoleucine is the endogenous bioactive jasmonate. Nat Chem Biol 5:344-350. https://doi.org/10.1038/nchembio.161

Foyer CH, Noctor G (2011) Ascorbate and glutathione: the heart of the redox hub. Plant Physiol 155:2-18. https://doi.org/10.1104/ pp.110.167569

Foyer CH, Noctor G (2016) Stress-triggered redox signalling: what's in pROSpect? Plant, Cell Environ 39:951-964. https://doi.org/ $10.1111 /$ pce. 12621

Gallego S, Kogan M, Azpilicueta C et al (2005) Glutathione-mediated antioxidative mechanisms in sunflower (Helianthus annuus L.) cells in response to cadmium stress. Plant Growth Regul 46:267276. https://doi.org/10.1007/s10725-005-0163-z
Gallego SM, Pena LB, Barcia RA et al (2012) Unravelling cadmium toxicity and tolerance in plants: insight into regulatory mechanisms. Environ Exp Bot 83:33-46. https://doi.org/10.1016/j. envexpbot.2012.04.006

Gallego SM, Benavides MP (2019) Cadmium-induced oxidative and nitrosative stress in plants. In: Hasanuzzaman M, Prasad MNV, Fujita M (eds) Cadmium Toxicity and Tolerance in Plants. Academic Press, From physiology to remediation

Gill SS, Tuteja N (2010) Reactive oxygen species and antioxidant machinery in abiotic stress tolerance in crop plants. Plant Physiol Biochem 48:909-930. https://doi.org/10.1016/j.plaphy.2010.08. 016

Godfray HCJ, Beddington JR, Crute IR et al (2010) Food security: the challenge of feeding 9 billion people. Science 327:812-818. https://doi.org/10.1126/science.1185383

Guo B, Liu C, Li H et al (2016) Endogenous salicylic acid is required for promoting cadmium tolerance of Arabidopsis by modulating glutathione metabolisms. J Hazard Mater 316:77-86. https://doi. org/10.1016/j.jhazmat.2016.05.032

Guo B (2019) Role of salicylic acid in mitigating cadmium toxicity in plants. In: Hasanuzzaman M, Prasad MNV, Fujita M (eds) Cadmium toxicity and tolerance in plants. Academic Press, From physiology to remediation

Han Y, Wang S, Zhao N et al (2016) Exogenous abscisic acid alleviates cadmium toxicity by restricting $\mathrm{Cd}^{2+}$ influx in Populus euphratica cells. J Plant Growth Regul 35:827-837. https://doi.org/10. 1007/s00344-016-9585-2

Hasanuzzaman M, Bhuyan MHMB, Anee TI et al (2019) Regulation of ascorbate-glutathione pathway in mitigating oxidative damage in plants under abiotic stress. Antioxidants 8:384. https://doi.org/ 10.3390/antiox 8090384

Hayat Q, Hayat S, Irfan M, Ahmad A (2010) Effect of exogenous salicylic acid under changing environment: a review. Environ Exp Bot 68:14-25. https://doi.org/10.1016/j.envexpbot.2009.08.005

Hoagland DR, Aron DI (1950) The water-culture method for growing plants without soil. California agricultural experimental station, the college of agriculture, university of California. Berkeley Circular 347:1-32

Hochholdinger F (2009) The maize root system: morphology, anatomy, and genetics. In: Bennetzen JL, Hake SC (eds) Handbook of Maize: Its Biology. Springer, New York

Hsu YT, Kao CH (2003) Role of abscisic acid in cadmium tolerance of rice (Oryza sativa L.) seedlings. Plant, Cell Environ 26:867-874. https://doi.org/10.1046/j.1365-3040.2003.01018.x

Hu YF, Zhou G, Na XF et al (2013) Cadmium interferes with maintenance of auxin homeostasis in Arabidopsis seedlings. J Plant Physiol 170:965-975. https://doi.org/10.1016/j.jplph.2013.02. 008

Hu B, Deng F, Chen G et al (2020) Evolution of abscisic acid signaling for stress responses to toxic metals and metalloids. Front Plant Sci 11:909. https://doi.org/10.3389/fpls.2020.00909

Huang D, Gong X, Liu Y et al (2017) Effects of calcium at toxic concentrations of cadmium in plants. Planta 245:863-873. https:// doi.org/10.1007/s00425-017-2664-1

Huang X, Duan S, Wu Q et al (2020) Reducing cadmium accumulation in plants: structure-function relations and tissue-specific operation of transporters in the spotlight. Plants 9:223. https://doi.org/ 10.3390/plants9020223

Hussain B, Li J, Ma Y et al (2020) Effects of Fe and Mn cations on Cd uptake by rice plant in hydroponic culture experiment. PLoS ONE 15(12):e0243174. https://doi.org/10.1371/journal.pone. 0243174

Jouili H, Bouazizi H, El Ferjani E (2011) Plant peroxidases: biomarkers of metallic stress. Acta Physiol Plant 33:2075-2082. https://doi. org/10.1007/s11738-011-0780-2 
Kim M, Ahn JW, Jin UH et al (2003) Activation of the programmed cell death pathway by inhibition of proteasome function in plants. J Biol Chem 278:19406-19415. https://doi.org/10.1074/jbc. M210539200

Kleczkowski LA, Igamberdiev AU (2021) Magnesium signaling in plants. Int J Mol Sci 22:1159. https://doi.org/10.3390/ijms2 2031159

Kudo H, Kudo K, Uemura M, Kawai S (2015) Magnesium inhibits cadmium translocation from roots to shoots, rather than the uptake from roots, in barley. Botany 93:345-351. https://doi.org/10. 1139/cjb-2015-0002

Kurotani K, Hayashi K, Hatanaka S et al (2015) Elevated levels of CYP94 family gene expression alleviate the jasmonate response and enhance salt tolerance in rice. Plant Cell Physiol 56:779789. https://doi.org/10.1093/pcp/pcv006

Laporte MA, Denaix L, Pagès L et al (2013) Longitudinal variation in cadmium influx in intact first order lateral roots of sunflower (Helianthus annuus. L). Plant Soil 372:581-595. https://doi.org/ 10.1007/s1104-013-1756-3

Law MY, Charles SA, Halliwell B (1983) Glutathione and ascorbic acid in spinach (Spinacia oleracea) chloroplasts. The effect of hydrogen peroxide and of Paraquat. Biochemical Journal 210:899-903. https://doi.org/10.1042/bj2100899

Lei GJ, Sun L, Sun Y et al (2020) Jasmonic acid alleviates cadmium toxicity in Arabidopsis via suppression of cadmium uptake and translocation. J Integr Plant Biol 62:218-227. https://doi.org/10. $1111 /$ jipb. 12801

Li M, Hao P, Cao F (2017) Glutathione-induced alleviation of cadmium toxicity in Zea mays. Plant Physiol Biochem 119:240-249. https://doi.org/10.1016/j.plaphy.2017.09.005

Li C, Liu Y, Tian J et al (2020a) Changes in sucrose metabolism in maize varieties with different cadmium sensitivities under cadmium stress. PLoS ONE 15(12):e0243835. https://doi.org/10. 1371/journal.pone.0243835

Li Z, Zhu J, Wang Y et al (2020b) Effects of exogenous indole acetic acid on growth and cadmium accumulation of Cyphomandra betacea seedlings. Int J Environ Anal Chem. https://doi.org/10. 1080/03067319.2020.1726336

Lin Z, Schneider A, Sterckeman T, Nguyen C (2016) Ranking of mechanisms governing the phytoavailability of cadmium in agricultural soils using a mechanistic model. Plant Soil 399:89-107. https://doi.org/10.1007/s11104-015-2663-6

Liu H, Zhang Y, Chai T et al (2013) Manganese-mitigation of cadmium toxicity to seedling growth of Phytolacca acinosa Roxb. is controlled by the manganese/cadmium molar ratio under hydroponic conditions. Plant Physiol Biochem 73:144-153. https://doi.org/ 10.1016/j.plaphy.2013.09.010

Liu K, Lv J, He W et al (2015a) Major factors influencing cadmium uptake from the soil into wheat plants. Ecotoxicol Environ Saf 113:207-213. https://doi.org/10.1016/j.ecoenv.2014.12.005

Liu T, Zhu S, Tang Q, Tang S (2015b) Genome-wide transcriptomic profiling of ramie (Boehmeria nivea $\mathrm{L}$. Gaud) in response to cadmium stress. Gene 558:131-137. https://doi.org/10.1016/j. gene.2014.12.057

Liu Y, Liu L, Qi J et al (2019) Cadmium activates ZmMPK3-1 and ZmMPK6-1 via induction of reactive oxygen species in maize roots. Biochem Biophys Res Commun 516:747-752. https://doi. org/10.1016/j.bbrc.2019.06.116

Lowry OH, Rosebrough NJ, Farr AL, Randal RJ (1951) Protein measurement with the Folin phenol reagent. J Biol Chem 193:265-275

Matayoshi CL, Pena LB, Arbona V et al (2020) Early responses of maize seedlings to $\mathrm{Cu}$ stress include sharp decreases in gibberellins and jasmonates in the root apex. Protoplasma 257:12431256. https://doi.org/10.1007/s00709-020-01504-1
Mazars C, Thuleau P, Lamotte O, Bourque S (2010) Cross-talk between ROS and calcium in regulation of nuclear activities. Mol Plant 3:706-718. https://doi.org/10.1093/mp/ssq024

Møller IM, Jensen PE, Hansson A (2007) Oxidative modifications to cellular components in plants. Annu Rev Plant Biol 58:459-481. https://doi.org/10.1146/annurev.arplant.58.032806.103946

Mostofa MG, Rahman A, Ansary M et al (2015) Hydrogen sulfide modulates cadmium-induced physiological and biochemical responses to alleviate cadmium toxicity in rice. Science Report. https://doi.org/10.1038/srep14078

Mostofa MG, Rahman MM, Ansary MMU, Fujita M, Tran L-SP (2019) Interactive effects of salicylic acid and nitric oxide in enhancing rice tolerance to cadmium stress. Int J Mol Sci 20(22):5798. https://doi.org/10.3390/ijms20225798

Nakano Y, Asada K (1981) Hydrogen peroxide is scavenged by ascorbate-specific peroxidase in spinach chloroplasts. Plant Cell Physiol 22:867-880. https://doi.org/10.1093/oxfordjournals.pcp. a076232

Nan Z, Li J, Zhang J, Cheng G (2002) Cadmium and zinc interactions and their transfer in soil-crop system under actual field conditions. Sci Total Environ 285:187-195. https://doi.org/10.1016/ S0048-9697(01)00919-6

Nyström T (2005) Role of oxidative carbonylation in protein quality control and senescence. EMBO J 24:1311-1317. https://doi.org/ 10.1038/sj.emboj.7600599

Pal'ove-Balang P, Kisová A, Pavlovkin J, MistríkI, (2006) Effect of manganese on cadmium toxicity in maize seedlings. Plant, Soil and Environ 52:143-149. https://doi.org/10.17221/3358-PSE

Palusińska M, Barabasz A, Kozak K et al (2020) Zn/Cd status-dependent accumulation of $\mathrm{Zn}$ and $\mathrm{Cd}$ in root parts in tobacco is accompanied by specific expression of ZIP genes. BMC Plant Biol 20:37. https://doi.org/10.1186/s12870-020-2255-3

Pena LB, Pasquini LA, Tomaro ML, Gallego SM (2007) 20S proteasome and accumulation of oxidized and ubiquitinated proteins in maize leaves subjected to cadmium stress. Phytochemistry 68:1139-1146. https://doi.org/10.1016/j.phytochem.2007.02.022

Pena LB, Azpilicueta CE, Gallego SM (2011) Sunflower cotyledons cope with copper stress by inducing catalase subunits less sensitive to oxidation. J Trace Elem Med Biol 25:125-129. https://doi. org/10.1016/j.jtemb.2011.05.001

Pequerul A, Pérez C, Madero P, Val J, Monge E (1993) A rapid wet digestion method for plant analysis. In: Fragoso MAC, Van Beusichem ML, Houwers A (eds) Optimization of plant nutrition. Developments in plant and soil sciences, Springer, Dordrecht

Piacentini D, Della Rovere F, Sofo A et al (2020) Nitric oxide cooperates with auxin to mitigate the alterations in the root system caused by cadmium and arsenic. Front Plant Sci 11:1182. https:// doi.org/10.3389/fpls.2020.01182

Piñeros MA, Shaff JE, Kochian LV (1998) Development, characterization, and application of a cadmium-selective microelectrode for the measurement of cadmium fluxes in roots of Thlaspi species and wheat. Plant Physiol 116:1393-1401. https://doi.org/ 10.1104/pp.116.4.1393

Polge C, Jaquinod M, Holzer F et al (2009) Evidence for the existence in Arabidopsis thaliana of the proteasome proteolytic pathway: activation in response to cadmium. J Biol Chem 284:3541235424. https://doi.org/10.1074/jbc.M109.035394

Popova LP, Maslenkova LT, Yordanova RY et al (2009) Exogenous treatment with salicylic acid attenuates cadmium toxicity in pea seedlings. Plant Physiol Biochem 47:224-231. https://doi.org/ 10.1016/j.plaphy.2008.11.007

Rahman A, Nahar K, Hasanuzzaman M, Fujita M (2016) Manganeseinduced cadmium stress tolerance in rice seedlings: coordinated action of antioxidant defense, glyoxalase system and nutrient homeostasis. CR Biol 339:462-474. https://doi.org/10.1016/j. crvi.2016.08.002 
Redjala T, Sterckeman T, Morel JL (2009) Cadmium uptake by roots: contribution of apoplast and of high- and low-affinity membrane transport systems. Environ Exp Bot 67:235-242. https://doi.org/ 10.1016/j.envexpbot.2009.05.012

Redjala T, Sterckeman T, Louis Morel J (2010) Determination of the different components of cadmium short-term uptake by roots. J Plant Nutr Soil Sci 173:935-945. https://doi.org/10.1002/jpln. 201000003

Rehman MZ, Rizwan M, Hussain A et al (2018) Alleviation of cadmium $(\mathrm{Cd})$ toxicity and minimizing its uptake in wheat (Triticum aestivum) by using organic carbon sources in Cd-spiked soil. Environ Pollut 241:557-565. https://doi.org/10.1016/j.envpol. 2018.06.005

Robyt JF, White BJ (1990) Biochemical techniques: theory and practice. Waveland Press, Prospect Heights

Ronzan M, Piacentini D, Fattorini L et al (2019) Auxin-jasmonate crosstalk in Oryza sativa L. root system formation after cadmium and/or arsenic exposure. Environ Exp Bot 165:59-69. https://doi. org/10.1016/j.envexpbot.2019.05.013

Santner A, Estelle M (2009) Recent advances and emerging trends in plant hormone signalling. Nature 459:1071-1078. https://doi.org/ 10.1038 /nature 08122

Seifikalhor M, Aliniaeifard S, Bernard F et al (2020) $\gamma$-Aminobutyric acid confers cadmium tolerance in maize plants by concerted regulation of polyamine metabolism and antioxidant defense systems. Sci Rep 10:3356. https://doi.org/10.1038/ s41598-020-59592-1

Shakirova FM, Allagulova CR, Maslennikova DR et al (2016) Salicylic acid-induced protection against cadmium toxicity in wheat plants. Environ Exp Bot 122:19-28. https://doi.org/10.1016/j. envexpbot.2015.08.002

Sharma I, Ahmad P (2014) Catalase: A versatile antioxidant in plants. In: Ahmad P (ed) Oxidative damage to plants. Academic Press, Antioxidant networks and signaling

Shen G, Niu J, Deng Z (2017) Abscisic acid treatment alleviates cadmium toxicity in purple flowering stalk (Brassica campestris L. ssp. chinensis var. purpurea Hort.) seedlings. Plant Physiol Biochem 118:471-478. https://doi.org/10.1016/j.plaphy.2017.07.018

Shulaev V, Oliver DJ (2006) Metabolic and proteomic markers for oxidative stress. New tools for reactive oxygen species research. Plant Physiol 141:367-372. https://doi.org/10.1104/pp.106. 077925

Siddiqi KS, Husen A (2019) Plant response to jasmonates: current developments and their role in changing environment. Bulletin of the National Research Centre 43:153. https://doi.org/10.1186/ s42269-019-0195-6

Singh I, Shah K (2014) Exogenous application of methyl jasmonate lowers the effect of cadmium-induced oxidative injury in rice seedlings. Phytochemistry 108:57-66. https://doi.org/10.1016/j. phytochem.2014.09.007

Singh S, Singh A, Bashri G, Prasad SM (2016) Impact of Cd stress on cellular functioning and its amelioration by phytohormones: an overview on regulatory network. Plant Growth Regul 80:253263. https://doi.org/10.1007/s10725-016-0170-2

Singh S, Singh VP, Prasad SM et al (2019) Interactive effect of silicon (Si) and salicylic acid (SA) in maize seedlings and their mechanisms of cadmium (Cd) toxicity alleviation. J Plant Growth Regul 38:1587-1597. https://doi.org/10.1007/s00344-019-09958-1

Sofo A, Scopa A, Nuzzaci M, Vitti A (2015) Ascorbate peroxidase and catalase activities and their genetic regulation in plants subjected to drought and salinity stresses. Int J Mol Sci 16:13561-13578. https://doi.org/10.3390/ijms160613561

Song L, Huang SC, Wise A et al (2016) A transcription factor hierarchy defines an environmental stress response network. Science. https://doi.org/10.1126/science.aag 1550
Steinhorst L, Kudla J (2013) Calcium and reactive oxygen species rule the waves of signaling. Plant Physiol 163:471-485. https://doi. org/10.1104/pp.113.222950

Sterckeman T, Thomine S (2020) Mechanisms of cadmium accumulation in plants. Crit Rev Plant Sci 39:322-359. https://doi.org/10. 1080/07352689.2020.1792179

Sterckeman T, Redjala T, Morel JL (2011) Influence of exposure solution composition and of plant cadmium content on root cadmium short-term uptake. Environ Exp Bot 74:131-139. https://doi.org/ 10.1016/j.envexpbot.2011.05.010

Sterckeman T, Gossiaux L, Guimont S et al (2018) Cadmium mass balance in French soils under annual crops: Scenarios for the next century. Sci Total Environ 639:1440-1452. https://doi.org/ 10.1016/j.scitotenv.2018.05.225

Tai H, Lu X, Opitz N et al (2016) Transcriptomic and anatomical complexity of primary, seminal, and crown roots highlight root typespecific functional diversity in maize (Zea mays L.). J Exp Bot 67:1123-1135. https://doi.org/10.1093/jxb/erv513

Tang RJ, Luan S (2017) Regulation of calcium and magnesium homeostasis in plants: from transporters to signaling network. Curr Opin Plant Biol 39:97-105. https://doi.org/10.1016/j.pbi.2017. 06.009

Tang Y, Wang L, Xie Y et al (2020) Effects of exogenous abscisic acid on the growth and cadmium accumulation of lettuce under cadmium-stress conditions. Int J Environ Anal Chem 100:720-731. https://doi.org/10.1080/03067319.2019.1639686

Thomine S, Wang R, Ward JM et al (2000) Cadmium and iron transport by members of a plant metal transporter family in Arabidopsis with homology to Nramp genes. Proc Natl Acad Sci 97:49914996. https://doi.org/10.1073/pnas.97.9.4991

Thor K (2019) Calcium-nutrient and messenger. Front Plant Sci 10:440. https://doi.org/10.3389/fpls.2019.00440

Vanstraelen M, Benková E (2012) Hormonal interactions in the regulation of plant development. Annu Rev Cell Dev Biol 28:463-487. https://doi.org/10.1146/annurev-cellbio-101011-155741

Vardhan KH, Kumar PS, Panda RC (2019) A review on heavy metal pollution, toxicity and remedial measures: current trends and future perspectives. J Mol Liq 290:111197. https://doi.org/10. 1016/j.molliq.2019.111197

Vatehová Z, Malovíková A, Kollárová K et al (2016) Impact of cadmium stress on two maize hybrids. Plant Physiol Biochem 108:90-98. https://doi.org/10.1016/j.plaphy.2016.06.035

Wehr NB, Levine RL (2012) Quantitation of protein carbonylation by dot blot. Anal Biochem 423:241-245. https://doi.org/10.1016/j. ab.2012.01.031

Wu D, Yamaji N, Yamane M et al (2016) The HvNramp5 transporter mediates uptake of cadmium and manganese, but not iron. Plant Physiol 172:1899-1910. https://doi.org/10.1104/pp.16.01189

Xu X, Liu C, Zhao X et al (2014) Involvement of an antioxidant defense system in the adaptive response to cadmium in maize seedlings (Zea mays L.). Bull Environ Contam Toxicol 93:618-624. https:// doi.org/10.1007/s00128-014-1361-z

Ye N, Li H, Zhu G et al (2014) Copper suppresses abscisic acid catabolism and catalase activity, and inhibits seed germination of rice. Plant Cell Physiol 55:2008-2016. https://doi.org/10.1093/pcp/ pcu136

Yi Z, Lehto NJ, Robinson BH, Cavanagh J-AE (2020) Environmental and edaphic factors affecting soil cadmium uptake by spinach, potatoes, onion and wheat. Sci Total Environ 713:136694. https://doi.org/10.1016/j.scitotenv.2020.136694

Zhang K, Wang G, Bao M et al (2019) Exogenous application of ascorbic acid mitigates cadmium toxicity and uptake in maize (Zea mays L.). Environ Sci Pollut Res 26:19261-19271. https://doi. org/10.1007/s11356-019-05265-0 
Zhang C, He Q, Wang M et al (2020) Exogenous indole acetic acid alleviates $\mathrm{Cd}$ toxicity in tea (Camellia sinensis). Ecotoxicol Environ Saf 190:110090. https://doi.org/10.1016/j.ecoenv.2019.110090

Zhou J, Cheng K, Huang G et al (2020) Effects of exogenous 3 -indoleacetic acid and cadmium stress on the physiological and biochemical characteristics of Cinnamomum camphora. Ecotoxicol Environ Saf 191:109998. https://doi.org/10.1016/j. ecoenv.2019.109998
Publisher's Note Springer Nature remains neutral with regard to jurisdictional claims in published maps and institutional affiliations. 